\title{
Effects of hourly, daily and seasonal variation of hazardous gases and climatic factors on the welfare of sheep housed in solid-floor confinement barns
}

\author{
S. Uzal Seyfi ${ }^{1 \#} \&$ F. Ilhan ${ }^{2}$ \\ ${ }^{1}$ Department of Farm Structure and Irrigation, Selçuk University, Konya, 42003 Türkiye \\ ${ }^{2}$ Department of Animal Science, Selçuk University, Konya, 42003 Türkiye
}

(Received 4 May 2018; Accepted 21 February 2019; First published online 17 May 2019)

\author{
Copyright resides with the authors in terms of the Creative Commons Attribution 4.0 South African License. \\ See: http://creativecommons.org/licenses/by/4.0/za \\ Condition of use: The user may copy, distribute, transmit and adapt the work, but must recognize the authors and \\ the South African Journal of Animal Science.
}

\begin{abstract}
Ambient air quality in livestock buildings is one of the most important factors affecting environmental pollution and global warming. Carbon dioxide $\left(\mathrm{CO}_{2}\right)$, methane $\left(\mathrm{CH}_{4}\right)$, ammonia $\left(\mathrm{NH}_{3}\right)$ and hydrogen sulphide $\left(\mathrm{H}_{2} \mathrm{~S}\right)$ are among the most hazardous gases in terms of human and animal health. The aim of this study was to determine the effect of hourly, daily and seasonal variations in the levels of hazardous gases, such as $\mathrm{CO}_{2}, \mathrm{CH}_{4}, \mathrm{NH}_{3}$ and $\mathrm{H}_{2} \mathrm{~S}$ in a solid-floor confinement sheep barn; as well as the effect of climatic parameters, temperature $(T)$, relative humidity $(\mathrm{RH})$ and air flow (AF) on animal welfare. The correlation between hazardous gases and climatic factors in the barn was also determined. The study was carried out on a sheep farm between July 2012 and June 2013 in Konya (Turkey) where few data are currently available on this subject. Climatic data were measured at intervals of five minutes at different points during this study, while hazardous gases were measured at the same intervals during the experimental periods (10 days for each season). All data were analysed by one-way analysis of variance (ANOVA) and Tukey's method was used to reveal intergroup differences. Cross-bilateral correlation between all data and different time periods was examined. There were significant differences between hourly and daily mean values of $\mathrm{CO}_{2}, \mathrm{NH}_{3}, \mathrm{~T}, \mathrm{RH}$ and AF. $\mathrm{CO}_{2}$ and $\mathrm{NH}_{3}$ levels showed a significant correlation with $\mathrm{T}$ and $\mathrm{RH}$. Unfortunately, $\mathrm{H}_{2} \mathrm{~S}$ and $\mathrm{CH}_{4}$ were below the level of detection in the study. Reducing the formation of these harmful gases, which have negative effects on animal production and cause environmental pollution, will be carried out with new sheep barn designs that take into account ambient air quality appropriate for animal welfare.
\end{abstract}

Keywords: Ambient air quality, animal production, $\mathrm{CH}_{4}, \mathrm{CO}_{2}$, environmental pollution, $\mathrm{H}_{2} \mathrm{~S}, \mathrm{NH}_{3}$, sheep barn

\#Corresponding author: seldauzal@selcuk.edu.tr

\section{Introduction}

Previous studies have indicated that the health and welfare of sheltered small ruminants can be significantly improved by factors such as regular checking of interior climate and sanitation (Budisatria et al., 2007). The ambient conditions in animal barns affect animal welfare, well-being and production directly; inadequate building design and inappropriate microclimates may give rise to thermal stress which threatens animal welfare (Clark \& McArthur, 1994). Livestock building conditions have a significant effect on animal welfare (Caroprese, 2008).

Agriculture is an important source of greenhouse gases which cause air pollution and climate change. In Europe and America, large-scale studies have been carried out which measure the emission rates of carbon dioxide $\left(\mathrm{CO}_{2}\right)$, methane $\left(\mathrm{CH}_{4}\right)$, ammonia $\left(\mathrm{NH}_{3}\right)$ and hydrogen sulphide $\left(\mathrm{H}_{2} \mathrm{~S}\right)$ in livestock buildings. In the latest Intergovernmental Panel on Climate Change report, agriculture alone is estimated to account for around $10 \%$ to $12 \%$ of global greenhouse gas emissions, and emissions from this sector are expected to rise until 2030 (Metz et al., 2007). Eighty percent of agricultural greenhouse gas emissions consists of nitrogen oxides from grassland and arable land that is used to grow feed crops, and methane from the digestive processes of ruminant animals such as cows and sheep (Anonymous, 2006). However, this issue has not received much attention in Turkey.

Ammonia and $\mathrm{H}_{2} \mathrm{~S}$ emissions, which are harmful gases to sheep and goats, have attracted particular attention in recent years (Blunden \& Anejera, 2008). These harmful gases in livestock buildings threaten the 
health of animals and people working in these buildings. Agriculture is regarded as a source of atmospheric $\mathrm{NH}_{3}$ in Europe and contributes to nearly half of global $\mathrm{NH}_{3}$ emissions (Asman, 1992). It has been reported in various scientific studies that $\mathrm{NH}_{3}$ emissions resulting from animal barns have also caused harmful effects in surrounding forests. Fangmeier et al. (1994) reported that in coniferous forests, high $\mathrm{NH}_{3}$ concentrations started tissue necrosis in the trees, leading to death of trees in advancing stages. Since $\mathrm{NH}_{3}$ has a high water solubility, diffusion into the atmosphere is faster when the fertiliser has been dried. Manure is processed as a solid, but the water it contains evaporates rapidly. For this reason, $\mathrm{NH}_{3}$ has the potential for gasification and diffusion regardless of the structure of the manure. Indoor and outdoor shelters, manure piles, anaerobic manure repositories, liquid and solid manure transport systems, and manure operations all contribute to this emission (Anonymous, 2001). Due to the short duration of $\mathrm{H}_{2} \mathrm{~S}$ in the atmosphere, the contribution of $\mathrm{H}_{2} \mathrm{~S}$ emissions from animal barns compared to other sources of $\mathrm{H}_{2} \mathrm{~S}$ is relatively low on the national scale for the formation of environmental problems. However, depending on the number and intensity of animal farms in the region, it may lead to significant environmental problems on a regional scale (Schnoor et al., 2002). The main source of $\mathrm{CO}_{2}$ in animal housing is the respiration of animals and people who work in the barn (Choiniere \& Munroe, 1997). Carbon dioxide emissions can also arise because of the microbial degradation of organic materials under aerobic and anaerobic conditions. Under aerobic conditions, $\mathrm{CO}_{2}$ and water are the final products, and all of the carbon is diffused as $\mathrm{CO}_{2}$. Under anaerobic conditions, microbial degradation of the organic material results in the formation of $\mathrm{CH}_{4}$ (Anonymous, 2001).

Wathes \& Charles (1994) and Olgun (2011) suggested that the maximum limit for persistent $\mathrm{NH}_{3}$ and $\mathrm{CO}_{2}$ emissions in livestock buildings is $20 \mathrm{ppm}$ and $3000 \mathrm{ppm}$, respectively. The optimum indoor temperature $(\mathrm{T})$ for sheep varies between 6 and $14{ }^{\circ} \mathrm{C}\left(14-16{ }^{\circ} \mathrm{C}\right.$ for fattening sheep) (Damm, 1997), and $10^{\circ} \mathrm{C}$ and $13^{\circ} \mathrm{C}$ (Olgun, 2011). If the relative humidity (RH) is constantly below $40 \%$, it can lead to excessive dust in the barn air and respiratory tract infections in sheep (Olgun, 2011). Optimal RH values for sheep that have been reported, are between $70 \%$ and $80 \%$ (Geigenmüller, 1992) and between $55 \%$ and $60 \%$ (Olgun, 2011). Sheep may be adversely affected by high RH. Indoor RH should not exceed $80 \%$ (Damm, 1997).

Modern livestock buildings, together with the increase in intensive animal production, have prompted warnings from scientists on the effects of a microclimate inside the building, management practices and animal welfare. In specialised sheep flocks, barn systems may offer improved welfare and health of animals by protecting sheep from heat- or cold-stress and by providing sufficient feed (Berge, 1997; Brosh et al., 1998). Published data indicate that many factors, such as protection from thermal extremes (Sevi et al., 2001), careful control of internal climatic conditions and hygiene (Curtis, 1983; Hartung, 1994), and adequate ventilation and lighting systems can noticeably improve the health and welfare of housed sheep.

In Turkey, there are not enough scientific studies to determine the gas emissions from animal housing and the effect of these gases on environmental pollution or global warming. In this context, studies should be carried out to determine the concentration of the gases generated in the ambient environment of animal housing and the emission of these gases from areas where livestock is intensively farmed. Accordingly, an inventory study should be carried out throughout the country and scientific studies should be supported (Kılıç \& Şimşek, 2009). In the research area, the demand for sheep and goat breeding increased in the period, 2010 to 2011. For this purpose, a new barn design appropriate for animal welfare that would have no negative effects such as global warming and environmental pollution, and provide animals with suitable breeding conditions, is needed. The farmers in the region mostly keep sheep and goats in solid-floor confinement barns on their farms during winter and spring seasons, and on pasture during the summer.

The aim of this study was to determine the effect of ambient air quality and some climatic factors on animal welfare, and hourly, daily and seasonal variations of measured $\mathrm{CO}_{2}, \mathrm{CH}_{4}, \mathrm{NH}_{3}$ and $\mathrm{H}_{2} \mathrm{~S}$ concentrations, and T, RH and air flow (AF) in a solid-floor confinement barn for sheep (a farming system used in the region) in Konya, Turkey. In the area where the study took place, intensive sheep farming is carried out. In addition to the calculated cross-bilateral correlation between hazardous gases, T, RH and AF for different seasons and different time periods, data which would identify the effects of ambient air quality parameters on animal behaviour, welfare, health, the health of people working in the barn and environmental air quality, are required.

\section{Materials and Methods}

The experimental sheep barn, built in 2012, was selected because it has a more modern structure than other sheep housing on the farm, and is commonly used. The plan of the farm and the solid-floor confinement sheep barn, and the measurement points for air quality, are presented in Figure 1 . The sheep barn housed 492 sheep. The farm capacity was 871 animals. Resting areas or closed area stocking density, open areas (for feeding), stocking density and trough length in the barn were $0.60 \mathrm{~m}^{2}, 1.20 \mathrm{~m}^{2}$ and $0.40 \mathrm{~m}$ per sheep, respectively. The barn floor was made of compacted clay. Manual feeding was carried out using traditional portable feeders (wooden and metallic). Sheep were fed and milked manually twice a day; feeding 
was carried out during morning and evening milking. Each sheep was given a quota of $0.5 \mathrm{~kg}$ concentrate; approximately $0.5 \mathrm{~kg}$ hay and cover (pellet feed, $0.5 \mathrm{~kg}$ per animal). While the sheep were taken to pasture twice a day in other seasons, they were fed three times a day during the winter when they were kept indoors. Water was available all day.

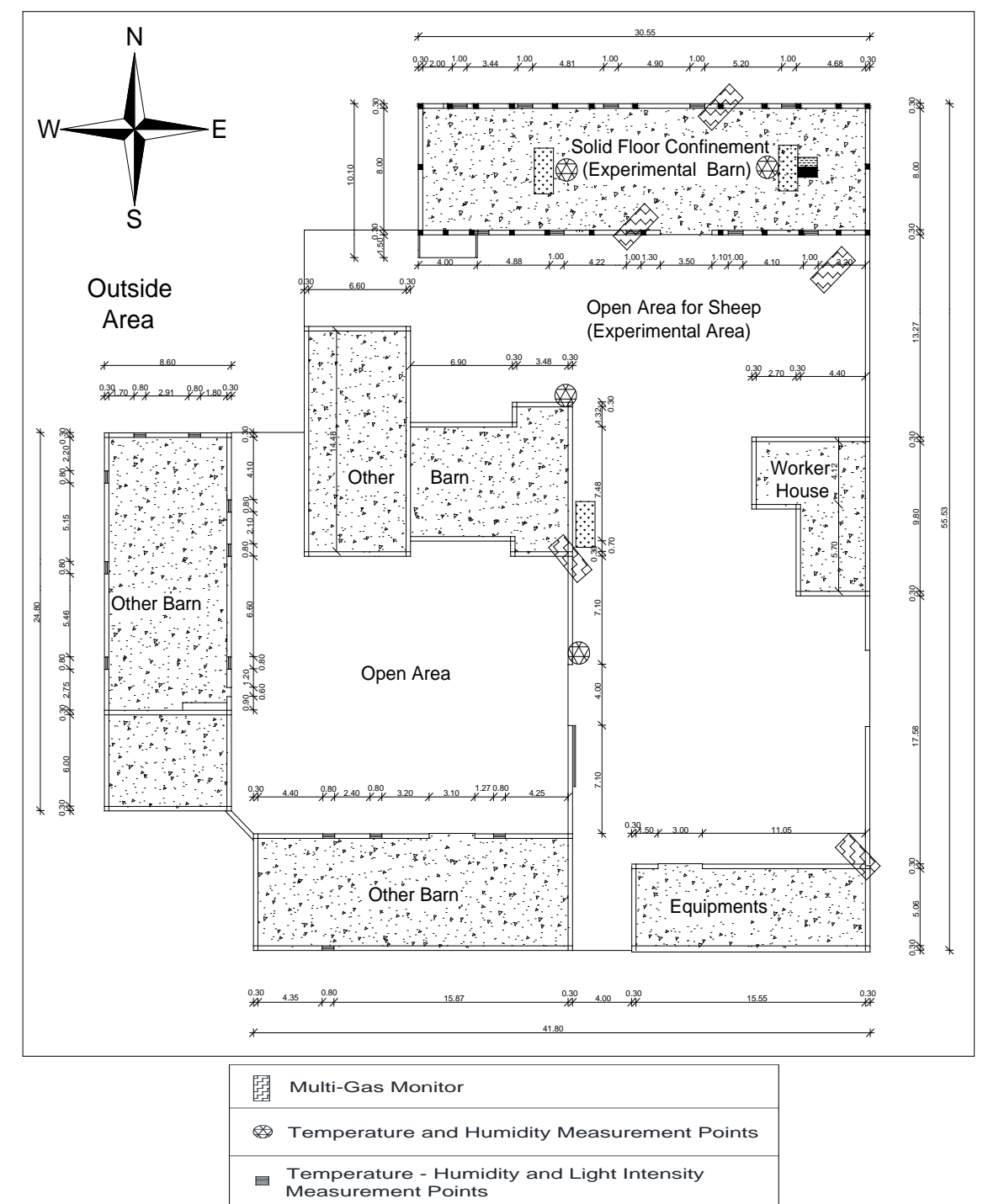

Figure 1 The plan of the farm and the solid-floor confinement sheep barn, and the measurement points for air quality

The study was carried out between July 2012 and June 2013 in Konya on a sheep farm with a solidfloor confinement barn. This study was planned to identify the variation of indoor air quality values in the barn during a one-year period. In the sheep farming system used in the region, sheep are housed on the farm during winter and spring seasons, while they are kept on pasture during the other seasons. In this study, measurements of hazardous gases in the barn during the year were taken. Because of the farming system used, this study was carried out during the winter and spring. Ten days, representing every season, were studied as recommended by Uzal Seyfi \& Dursun (2011). The experimental periods in this study were January 21 to 31 for the winter season, and April 22 to May 1 for the spring season; totalling 20 days for determining the ambient air quality parameters.

Climatic data were measured at five-minute intervals at the different points during this study, while hazardous gases were measured at the same intervals during the experimental periods. All data obtained in the study were collected from the farm using equipment fixed at a suitable position on the sheep farm (Figure 1). All devices in this study were located slightly above the height of an animal (1.20 to $1.30 \mathrm{~m}$ above the 
barn floor), as suggested by Uzal Seyfi (2013), Walker et al. (2006) and Phillips et al. (2004), taped to a pole and shaded from direct sunlight.

Levels of hazardous gases $\left(\mathrm{NH}_{3}, \mathrm{CO}_{2}, \mathrm{CH}_{4}\right.$ and $\left.\mathrm{H}_{2} \mathrm{~S}\right)$ were measured at two different points in a closed area (resting area) in the sheep barn during the experimental periods. Climatic measurements $(\mathrm{T}, \mathrm{RH}$ and $\mathrm{AF}$ ) were taken at three different points in a closed area and two different points in an open area and one point in an external area, totalling six points during the experimental periods. Digital temperature, humidity and light intensity metres were used to measure climatic data on the sheep farm (temperature measuring range $\left(-49{ }^{\circ} \mathrm{C}\right)-\left(+100{ }^{\circ} \mathrm{C}\right)$; resolution $0.03^{\circ} \mathrm{C}$; accuracy $\pm 0.33^{\circ} \mathrm{C}$; relative humidity measuring range 0\% - 100\%; resolution 0.4\%; accuracy $\pm 3 \%$; Hobo Data Logger, Onset Computer Corporation, USA). External climatic conditions were measured with a climatic station: external temperature measurement range $\left(-40{ }^{\circ} \mathrm{C}\right)\left(+65^{\circ} \mathrm{C}\right)$; resolution $0.1{ }^{\circ} \mathrm{C}$; accuracy $\pm 0.5^{\circ} \mathrm{C}$. The relative humidity measurement rate $1 \%-100 \%$; resolution 1\%; accuracy $3 \%$; internal dew point temperature measurement range $\left(-50{ }^{\circ} \mathrm{C}\right)-\left(+60{ }^{\circ} \mathrm{C}\right)$; resolution $0.1{ }^{\circ} \mathrm{C}$; accuracy $\pm 1.5^{\circ} \mathrm{C}$; external dew point temperature measurement range $\left(-76{ }^{\circ} \mathrm{C}\right)-\left(+54^{\circ} \mathrm{C}\right)$; resolution $1{ }^{\circ} \mathrm{C}$; accuracy $\pm 1.5^{\circ} \mathrm{C}$; rainfall measurement range $0-6553 \mathrm{~mm}$; resolution $0.2 \mathrm{~mm}$; accuracy $4 \%$; rainfall rate measurement range $0-2438 \mathrm{~mm} / \mathrm{h}$; resolution $0.1 \mathrm{~mm} / \mathrm{h}$; accuracy $5 \%<127 \mathrm{~mm} / \mathrm{h}$; solar radiation measurement range $0-1800 \mathrm{~W} / \mathrm{m}^{2}$; resolution $1 \mathrm{~W} / \mathrm{m}^{2}$; accuracy $5 \%$; wind direction measurement range 0 - 360; resolution 1 ; accuracy \pm 3 ; wind velocity measurement range $1-80 \mathrm{~m} / \mathrm{sec}$; resolution 0.1 $\mathrm{m} / \mathrm{sec}$; accuracy $\pm 5 \frac{1}{2}$. The levels of $\mathrm{NH}_{3}, \mathrm{CO}_{2}, \mathrm{CH}_{4}$ and $\mathrm{H}_{2} \mathrm{~S}$ in the barn were measured using a multi-gas monitor: measurement range and resolution $0-500 \mathrm{ppm}$ and $0.1 \mathrm{ppm}$ for $\mathrm{H}_{2} \mathrm{~S} ; 0 \%-5 \%$, and $0.1 \%$ for $\mathrm{CH}_{4} ; 0$ - $100 \mathrm{ppm}$ and $1.0 \mathrm{ppm}$ for $\mathrm{NH}_{3}$ operating conditions of the device; $20-45^{\circ} \mathrm{C}$ for $\mathrm{T}$ and $0 \%-85 \%$ for relative humidity (MultiRAE, RAE Systems Inc, USA). All data in the study were measured at intervals of five minutes at the different points.

All the data obtained were evaluated electronically with the aid of a computer, and were subjected to variance analysis (one-way ANOVA) in order to determine seasonal, daily and hourly variations, and Tukey's method was applied to reveal intergroup differences (Minitab, 2013). In addition, the hourly minimum, maximum, and mean values of all data were presented as graphs. Cross-bilateral correlation analysis and regression analysis were applied to all data (Minitab, 2013). An overview of correlations between parameters was obtained by principle component analysis (PCA) using Minitab 16. Processing was carried out in accordance with standardised variables, i.e. variables calculated by deducting the mean and then dividing by the standard deviation of each original variable to eliminate distortion due to the dissimilarity in the variables of the various units.

\section{Results and Discussion}

All data obtained from this study were subjected to cross-bilateral correlation and regression analysis. The cross-bilateral correlations between $\mathrm{T}, \mathrm{RH}, \mathrm{CO}_{2}, \mathrm{NH}_{3}$ and $\mathrm{AF}$ for the day-time and night-time data in winter, are presented in Table 1. The $\mathrm{CO}_{2}$ and $\mathrm{NH}_{3}$ levels showed a significant correlation with $\mathrm{T}$ and $\mathrm{RH}$ for the day-time experimental period ( $r: 0.699 ; P<0.05)$. There was an important correlation between $\mathrm{NH}_{3}$ and $\mathrm{RH}$ for night-time periods ( $\mathrm{r}$ : $0.635 ; P<0.05$ ). There was no significant association between $\mathrm{T}$ with $\mathrm{CO}_{2}$ and $\mathrm{NH}_{3}$ at both day-time and night-time periods.

Equations 1 and 3 display the results of multiple regressions for $\mathrm{CO}_{2}$ with other parameters for daytime and night-time periods. Equations 2 and 4 display the results of multiple regressions for $\mathrm{NH}_{3}$ with other parameters in day-time and night-time periods. It was determined that the differences in $\mathrm{CO}_{2}$ concentration in the regression model could be defined as $36.1 \%$ and $18.6 \%$ by $\mathrm{T}, \mathrm{RH}$ and $\mathrm{AF}$ in day-time and night-time, respectively. Also, it was determined that the variation in $\mathrm{NH}_{3}$ concentration in the regression model could be defined as $44.3 \%$ and $54.1 \%$ by the other parameters and AF in day-time and night-time experimental periods, respectively.

$$
\begin{aligned}
& \mathrm{CO}_{2}(\mathrm{D})=-2251+39 \mathrm{Temp}+32.4 \mathrm{RH}-9.83 \mathrm{NH}_{3}-1886 \mathrm{AF} \\
& \mathrm{NH}_{3}(\mathrm{D})=-85+6.12 \mathrm{Temp}+0.63 \mathrm{RH}-0.0251 \mathrm{CO}_{2}-385 \mathrm{AF} \\
& \mathrm{CO}_{2}(\mathrm{~N})=2221-2.4 \mathrm{Temp}-10.8 \mathrm{RH}+3.71 \mathrm{NH}_{3}+1626 \mathrm{AF} \\
& \mathrm{NH}_{3}(\mathrm{~N})=-382+3.05 \mathrm{Temp}+3.42 \mathrm{RH}+0.0443 \mathrm{CO}_{2}-240 \mathrm{AF}
\end{aligned}
$$

$$
\begin{array}{ll}
\mathrm{R}^{2}=36.1 \% & \mathrm{Eq}(1) \\
\mathrm{R}^{2}=44.3 \% & \mathrm{Eq(2)} \\
\mathrm{R}^{2}=18.6 \% & \mathrm{Eq}(3) \\
\mathrm{R}^{2}=54.1 \% & \mathrm{Eq}(4)
\end{array}
$$

The summary of statistical analyses, the cross-bilateral correlation between $\mathrm{T}, \mathrm{RH}, \mathrm{CO}_{2}, \mathrm{NH}_{3}$ and $\mathrm{AF}$ for day-time and night-time in the spring season are presented in Table 2. Examination of Table 2 shows a statistical significance between $\mathrm{T}$ and $\mathrm{NH}_{3}$ in day-time and night-time experimental periods $(P<0.01)$, and with $\mathrm{CO}_{2}$ for day-time $(P<0.05)$. There was a significant inverse relationship between $\mathrm{NH}_{3}$ and $\mathrm{RH}$ in nighttime $(P<0.01)$ and day-time periods. There was a significant inverse relationship between $\mathrm{T}$ with $\mathrm{RH}$ for night-time $(P<0.01)$ and day-time periods $(P<0.05)$. There was no significant relationship between $\mathrm{T}$ and $\mathrm{AF}$ 
in either day-time or night-time periods. There was a statistically significant relationship between $\mathrm{NH}_{3}$ with $\mathrm{CO}_{2}$ in day-time $(P<0.05)$ and night-time experimental periods.

Table 1 The cross-bilateral correlation between temperature, relative humidity, $\mathrm{CO}_{2}, \mathrm{NH}_{3}$ and air flow for day-time and night-time in the winter season

\begin{tabular}{|c|c|c|c|c|c|c|c|c|c|c|}
\hline \multirow{2}{*}{ Time } & \multirow[b]{2}{*}{ Parameters } & \multicolumn{5}{|c|}{ Day } & \multicolumn{4}{|c|}{ Night } \\
\hline & & Temp & RH & $\mathrm{CO}_{2}$ & $\mathrm{NH}_{3}$ & AF & Temp & $\mathbf{R H}$ & $\mathrm{CO}_{2}$ & $\mathrm{NH}_{3}$ \\
\hline \multirow{4}{*}{ Day } & $\mathrm{RH}$ & $0.699^{*}$ & & & & & & & & \\
\hline & $\mathrm{CO}_{2}$ & 0.226 & 0.378 & & & & & & & \\
\hline & $\mathrm{NH}_{3}$ & 0.434 & 0.345 & -0.298 & & & & & & \\
\hline & $\mathrm{AF}$ & 0.146 & -0.156 & -0.005 & -0.198 & & & & & \\
\hline \multirow{5}{*}{ Night } & Temp & $0.803^{\star \star}$ & $0.724^{*}$ & 0.182 & $0.640 *$ & 0.001 & & & & \\
\hline & $\mathrm{RH}$ & 0.550 & -0.031 & 0.126 & 0.234 & 0.229 & 0.241 & & & \\
\hline & $\mathrm{CO}_{2}$ & 0.304 & 0.646 & 0.651 & -0.112 & -0.151 & 0.124 & 0.094 & & \\
\hline & $\mathrm{NH}_{3}$ & 0.587 & 0.381 & -0.090 & 0.185 & -0.098 & 0.329 & $0.635^{\star}$ & 0.365 & \\
\hline & $\mathrm{AF}$ & 0.255 & 0.124 & -0.151 & -0.406 & $0.648^{*}$ & 0.226 & 0.196 & 0.113 & 0.04 \\
\hline
\end{tabular}

*(P<0.05); ** $(P<0.01)$

$\mathrm{CO}_{2}$; carbon dioxide, $\mathrm{NH}_{3}$; ammonia, $\mathrm{T}$; temperature, $\mathrm{RH}$; relative humidity, $\mathrm{AF}$; air flow

Table 2 The cross-bilateral correlation between temperature, relative humidity, $\mathrm{CO}_{2}, \mathrm{NH}_{3}$ and air flow for day-time and night-time in the spring season

\begin{tabular}{|c|c|c|c|c|c|c|c|c|c|c|}
\hline \multirow{2}{*}{ Time } & & \multicolumn{5}{|c|}{ Day } & \multicolumn{4}{|c|}{ Night } \\
\hline & & $\mathbf{T}$ & $\mathbf{R H}$ & $\mathrm{CO}_{2}$ & $\mathrm{NH}_{3}$ & AF & $\mathbf{T}$ & $\mathbf{R H}$ & $\mathrm{CO}_{2}$ & $\mathrm{NH}_{3}$ \\
\hline \multirow{4}{*}{ Day } & $\mathrm{RH}$ & $-0.634^{*}$ & & & & & & & & \\
\hline & $\mathrm{CO}_{2}$ & $0.749 *$ & -0.291 & & & & & & & \\
\hline & $\mathrm{NH}_{3}$ & $0.875^{\star \star}$ & -0.450 & $0.744^{*}$ & & & & & & \\
\hline & $\mathrm{AF}$ & 0.065 & -0.147 & -0.087 & -0.081 & & & & & \\
\hline \multirow{5}{*}{ Night } & $\mathrm{T}$ & 0.970 ** & -0.543 & $0.714^{*}$ & $0.861^{\star *}$ & -0.022 & & & & \\
\hline & $\mathrm{RH}$ & $-0.818^{*}$ & $0.762^{*}$ & -0.480 & $-0.662^{*}$ & 0.060 & $-0.858^{\star \star}$ & & & \\
\hline & $\mathrm{CO}_{2}$ & 0.286 & 0.024 & $0.669^{*}$ & 0.409 & -0.198 & 0.385 & -0.365 & & \\
\hline & $\mathrm{NH}_{3}$ & $0.774^{\star}$ & -0.334 & 0.625 & $0.867^{\star *}$ & -0.244 & $0.877^{\star *}$ & $-0.778^{\star \star}$ & 0.582 & \\
\hline & $\mathrm{AF}$ & -0.119 & 0.156 & 0.042 & -0.028 & $-0.884^{\star \star}$ & -0.038 & 0.076 & 0.031 & 0.129 \\
\hline
\end{tabular}

* $(P<0.05) ;$ ** $(P<0.01)$

$\mathrm{CO}_{2}$; carbon dioxide, $\mathrm{NH}_{3}$; ammonia, $\mathrm{T}$; temperature, $\mathrm{RH}$; relative humidity, $\mathrm{AF}$; air flow

Equations 5 and 7 show results of the multiple regressions for $\mathrm{CO}_{2}$ with other parameters in day-time and night-time periods. Equations 6 and 8 show the results of multiple regressions for $\mathrm{NH}_{3}$ with other parameters in day-time and night-time periods for solid-floor confinement with lot sheep housed in a barn. It was determined that the variations in the $\mathrm{NH}_{3}$ concentration in the regression model were $79.0 \%$ and $89.2 \%$ by $\mathrm{T}, \mathrm{RH}$ and $\mathrm{AF}$ in day-time and night-time, respectively. It was also determined that the variation in the $\mathrm{CO}_{2}$ concentration in the regression model was $63.7 \%$, and $47.4 \%$ by the other parameters and AF in day-time and night-time experimental periods, respectively. 


$$
\begin{aligned}
& \mathrm{CO}_{2}(\mathrm{D})=-37.8+1.66 \mathrm{Temp}+0.180 \mathrm{RH}+0.0051 \mathrm{NH}_{3}-40 \mathrm{AF} \\
& \mathrm{NH}_{3}(\mathrm{D})=-1127+70.3 \mathrm{Temp}+4.36 \mathrm{RH}+3.5 \mathrm{CO}_{2}+5873 \mathrm{AF} \\
& \mathrm{CO}_{2}(\mathrm{~N})=30-1.79 \mathrm{Temp}+0.043 \mathrm{RH}+0.0413 \mathrm{NH}_{3}-318 \mathrm{AF} \\
& \mathrm{NH}_{3}(\mathrm{~N})=-830+65.7 \mathrm{Temp}-2.5 \mathrm{RH}+7.82 \mathrm{CO}_{2}+8137 \mathrm{AF}
\end{aligned}
$$

$$
\begin{array}{ll}
\mathrm{R}^{2}=63.7 \% & \mathrm{Eq}(5) \\
\mathrm{R}^{2}=79.0 \% & \mathrm{Eq}(6) \\
\mathrm{R}^{2}=47.4 \% & \mathrm{Eq}(7) \\
\mathrm{R}^{2}=89.2 \% & \mathrm{Eq}(8)
\end{array}
$$

The data obtained from the studied sheep barn were subjected to variance analysis. The results of the analysis for different seasons are presented in Tables $3 \mathrm{a}$ and $3 \mathrm{~b}$. The hourly changes in some climatic data during the winter and spring experimental periods in the solid-floor confinement sheep barn are presented in Figures 2 and 3. The differences in hourly mean values of $\mathrm{CO}_{2}, \mathrm{NH}_{3}, \mathrm{~T}, \mathrm{RH}$ and AF were statistically significant $\left(P<0.01\right.$; Table 3a; 3b). In winter, the highest and lowest $\mathrm{CO}_{2}$ values were measured at $1: 00$ and 17:00 (1553.3 ppm and $794.7 \mathrm{ppm}$, respectively). The variations between $\mathrm{CO}_{2}$ values were statistically significant $(P<0.01)$. The highest value for $\mathrm{NH}_{3}$ concentration was measured at 22:00 (18.32 ppm), and the lowest value at $14: 00$ (4.14 ppm). The $\mathrm{T}$ was between $9.89{ }^{\circ} \mathrm{C}$ and $13.23{ }^{\circ} \mathrm{C}$. $\mathrm{T}$ values measured in the winter experimental period are suitable $\mathrm{T}$ for sheep (Ekmekyapar, 2001; Olgun, 2011). $\mathrm{NH}_{3}$ and carbon dioxide were occasionally at a very high level, which may affect sheep health. T, RH and AF were usually at values that are suitable for the optimum health and welfare of sheep.

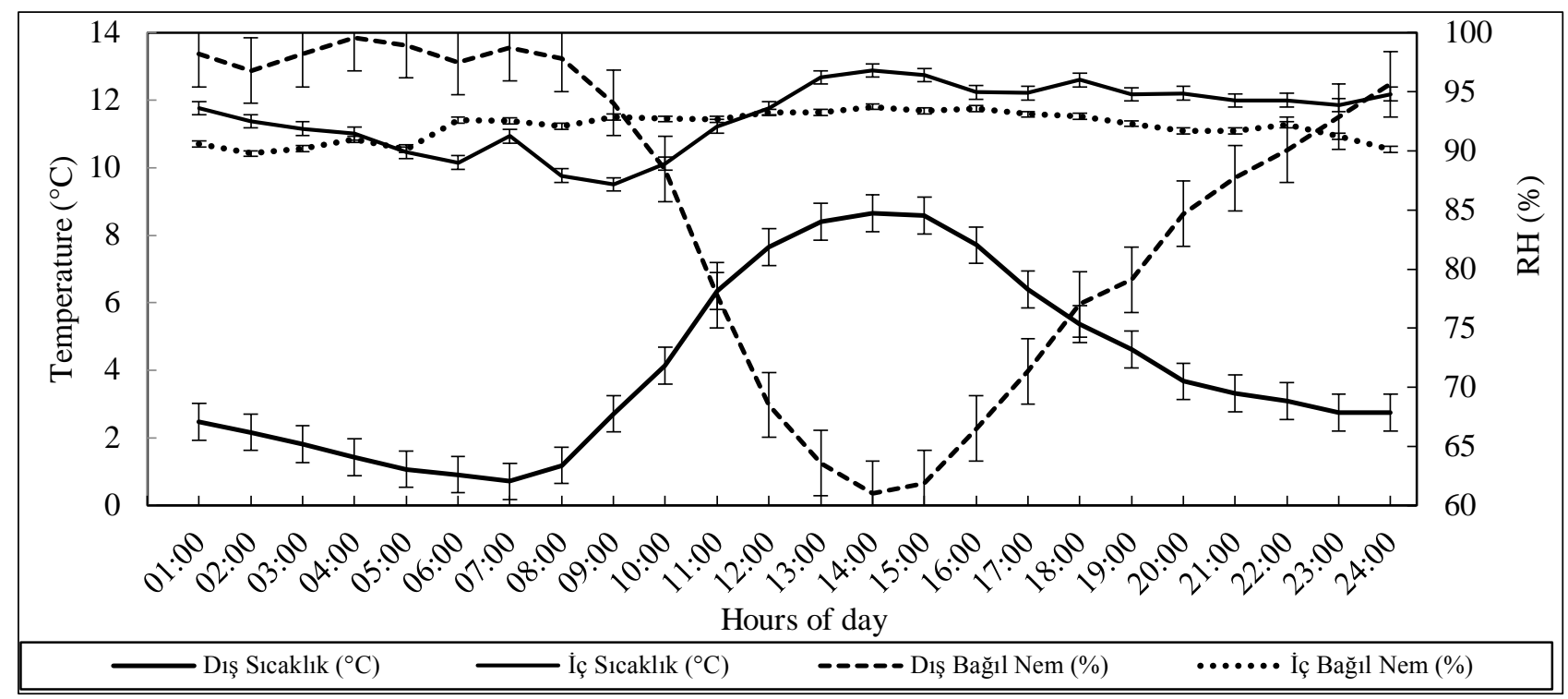

Figure 2 The hourly distribution of mean temperature and relative humidity $(\mathrm{RH})$ in solid-floor confinement sheep barn in winter

The mean values for $\mathrm{T}$ and $\mathrm{RH}$ outside the sheep barn were in the range $0.7-8.7{ }^{\circ} \mathrm{C}$ and $61 \%$ $100 \%$, respectively, during the winter experimental period. $\mathrm{T}$ and $\mathrm{RH}$ showed an inverse relationship. There was a difference of $4-5{ }^{\circ} \mathrm{C}$ between inside and outside T during the day-time (between 11:00 and 16:00), while this value was $6-10^{\circ} \mathrm{C}$ for night-time (between 18:00 and 10:00; Figure 2). The lowest inside T of 9.9 ${ }^{\circ} \mathrm{C}$ was detected at 9:00, the second lowest $\left(10.2^{\circ} \mathrm{C}\right)$ at $8: 00$ and the highest $\left(13.2^{\circ} \mathrm{C}\right)$ at $14: 00$. The inside $\mathrm{T}$ was higher than $10{ }^{\circ} \mathrm{C}$ during the day-time. Olgun (2011), Damm (1997) and Ekmekyapar (1991) reported the optimum inside T for sheep to be $10-13^{\circ} \mathrm{C}$. Uğurlu \& Uzal Seyfi (2010) reported the range $4-24{ }^{\circ} \mathrm{C}$ to be the appropriate T. Data on T inside the experimental sheep barn in the present study showed suitable values for animals during the winter season. The lowest $\mathrm{RH}$ value inside the barn (90\%) was at 0:00, 2:00, 3:00 and 5:00, and the highest value (94\%) 14:00 and 16:00 (Figure 2). The difference between RH inside and outside the barn was $2 \%$ and $33 \%$. This difference was $13 \%$ - 33\% in the day-time and 1\% - 9\% during the night-time. The situation was different in the closed sheep pen during the winter season. The value of RH inside the barn was lower than outside between 23:00 and 9:00. That was a result of the higher inside $\mathrm{T}$ and no night-time ventilation. $\mathrm{RH}$ inside the barn was higher than outside by $22 \%-33 \%$, between $12: 00$ and 17:00. Although a value of $80 \% \mathrm{RH}$ is reachable, the optimum value is $50 \%-60 \%$ (Geingenmüller, 1992; Damm, 1997). The RH values obtained in this study were higher than the permitted values. Thus, regulation of the ventilation is needed to achieve $\mathrm{RH}$ levels suitable for sheep health, welfare and productivity. 
Table 3a The hourly variation in the mean values of $\mathrm{CO}_{2}, \mathrm{NH}_{3}$, temperature, relative humidity, and air flow in the solid-floor confinement barn during winter season (MEAN \pm SEM)

\begin{tabular}{|c|c|c|c|c|c|c|}
\hline & \multirow{2}{*}{ Time } & \multicolumn{5}{|c|}{ Winter } \\
\hline & & $\mathrm{CO}_{2}(\mathrm{ppm})$ & $\mathrm{NH}_{3}(\mathrm{ppm})$ & $\mathrm{T}\left({ }^{\circ} \mathrm{C}\right)$ & RH (\%) & $\mathrm{AF}(\mathrm{m} / \mathrm{s})$ \\
\hline \multirow{24}{*}{ 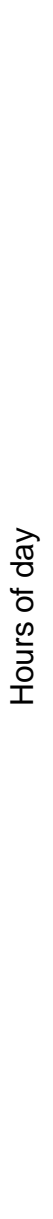 } & 01:00 & $1480.0^{\mathrm{ab}} \pm 56.6$ & $13.47 \pm 7.31$ & $12.12^{\mathrm{abc}} \pm 0.38$ & $92.53 \pm 0.91$ & $0.24^{b} \pm 0.027$ \\
\hline & 02:00 & $1400.0^{\mathrm{abc}} \pm 67.7$ & $13.69 \pm 6.86$ & $11.77^{\mathrm{abc}} \pm 0.34$ & $91.79 \pm 1.02$ & $0.29^{a} \pm 0.010$ \\
\hline & 03:00 & $1390.0^{\mathrm{abc}} \pm 78.0$ & $13.41 \pm 6.65$ & $11.61^{\mathrm{abc}} \pm 0.40$ & $92.08 \pm 1.17$ & $0.1^{c} \pm 0.000$ \\
\hline & 04:00 & $1351.7^{\mathrm{abcd}} \pm 82.7$ & $10.59 \pm 6.46$ & $11.49^{\mathrm{abc}} \pm 0.45$ & $92.18 \pm 1.17$ & $0.1^{c} \pm 0.000$ \\
\hline & 05:00 & $1298.3^{\mathrm{abcd}} \pm 94.6$ & $15.74 \pm 9.15$ & $10.99^{\mathrm{abc}} \pm 0.46$ & $91.69 \pm 1.32$ & $0.1^{c} \pm 0.000$ \\
\hline & 06:00 & $1335.0^{\mathrm{abcd}} \pm 95.7$ & $11.76 \pm 8.03$ & $10.67^{\mathrm{abc}} \pm 0.49$ & $91.49 \pm 1.26$ & $0.1^{\mathrm{c}} \pm 0.000$ \\
\hline & 07:00 & $1346.7^{\mathrm{abcd}} \pm 86.0$ & $11.92 \pm 7.25$ & $11.49^{\mathrm{abc}} \pm 0.46$ & $91.42 \pm 1.79$ & $0.1^{c} \pm 0.000$ \\
\hline & 08:00 & $1266.7^{\mathrm{abcd}} \pm 89.8$ & $14.36 \pm 7.55$ & $10.16^{\mathrm{bc}} \pm 0.45$ & $90.93 \pm 2.17$ & $0.1^{c} \pm 0.000$ \\
\hline & 09:00 & $1145.0^{\mathrm{abcd}} \pm 145.9$ & $9.14 \pm 5.99$ & $9.89^{c} \pm 0.52$ & $91.79 \pm 2.12$ & $0.1^{\mathrm{c}} \pm 0.000$ \\
\hline & 10:00 & $1055.0^{\mathrm{abcd}} \pm 157.2$ & $4.83 \pm 4.82$ & $10.55^{\mathrm{abc}} \pm 0.49$ & $91.62 \pm 1.71$ & $0.1^{c} \pm 0.000$ \\
\hline & $11: 00$ & $1033.3^{\mathrm{abcd}} \pm 93.1$ & $4.68 \pm 4.66$ & $11.53^{\mathrm{abc}} \pm 0.52$ & $91.60 \pm 1.63$ & $0.1^{\mathrm{c}} \pm 0.000$ \\
\hline & $12: 00$ & $913.3^{\mathrm{bcd}} \pm 126.5$ & $4.23 \pm 4.22$ & $12.04^{\mathrm{abc}} \pm 0.49$ & $92.24 \pm 1.19$ & $0.1^{c} \pm 0.000$ \\
\hline & 13:00 & $956.7^{\mathrm{bcd}} \pm 147.1$ & $4.14 \pm 4.13$ & $13.01^{\mathrm{ab}} \pm 0.53$ & $92.23 \pm 0.96$ & $0.1^{c} \pm 0.000$ \\
\hline & $14: 00$ & $928.3^{\mathrm{bcd}} \pm 125.8$ & $4.29 \pm 4.28$ & $13.23^{\mathrm{a}} \pm 0.63$ & $92.75 \pm 1.00$ & $0.1^{c} \pm 0.000$ \\
\hline & $15: 00$ & $903.3^{\mathrm{bcd}} \pm 125.5$ & $7.21 \pm 4.83$ & $13.11^{\mathrm{ab}} \pm 0.75$ & $92.39 \pm 1.06$ & $0.1^{\mathrm{c}} \pm 0.000$ \\
\hline & $16: 00$ & $794.7^{d} \pm 198.5$ & $11.17 \pm 7.94$ & $12.84^{\mathrm{abc}} \pm 0.82$ & $92.57 \pm 1.14$ & $0.26^{\mathrm{ab}} \pm 0.027$ \\
\hline & $17: 00$ & $815.0^{c d} \pm 160.8$ & $5.01 \pm 4.04$ & $12.57^{\mathrm{abc}} \pm 0.71$ & $92.06 \pm 1.06$ & $0.30^{\mathrm{a}} \pm 0.000$ \\
\hline & 18:00 & $1158.3^{\mathrm{abcd}} \pm 95.7$ & $12.64 \pm 9.14$ & $12.99^{\mathrm{ab}} \pm 0.71$ & $91.85 \pm 1.57$ & $0.1^{c} \pm 0.000$ \\
\hline & 19:00 & $1348.3^{\mathrm{abcd}} \pm 113.2$ & $12.52 \pm 8.49$ & $12.53^{\mathrm{abc}} \pm 0.71$ & $91.18 \pm 1.71$ & $0.1^{c} \pm 0.000$ \\
\hline & $20: 00$ & $1401.7^{\mathrm{abc}} \pm 107.1$ & $14.76 \pm 7.60$ & $12.61^{\mathrm{abc}} \pm 0.73$ & $90.51 \pm 1.84$ & $0.1^{\mathrm{c}} \pm 0.000$ \\
\hline & 21:00 & 1313. $3^{\mathrm{abcd}} \pm 90.9$ & $18.32 \pm 10.12$ & $12.38^{\mathrm{abc}} \pm 0.72$ & $90.49 \pm 2.20$ & $0.1^{\mathrm{c}} \pm 0.000$ \\
\hline & 22:00 & $1270.0^{\mathrm{abcd}} \pm 70.4$ & $15.52 \pm 8.42$ & $12.42^{\mathrm{abc}} \pm 0.64$ & $91.09 \pm 2.08$ & $0.1^{c} \pm 0.000$ \\
\hline & 23:00 & $1430.0^{\mathrm{ab}} \pm 101.4$ & $12.31 \pm 7.35$ & $12.22^{\mathrm{abc}} \pm 0.66$ & $89.98 \pm 2.36$ & $0.1^{c} \pm 0.000$ \\
\hline & $24: 00$ & $1553.3^{\mathrm{a}} \pm 75.3$ & $13.52 \pm 8.02$ & $12.54^{\mathrm{abc}} \pm 0.42$ & $92.63 \pm 1.03$ & $0.01^{c} \pm 0.000$ \\
\hline
\end{tabular}

a b c de f:The differences between the means with the different letter in the same column are statistically important. Mean: Average \pm SEM: Standard Error Mean. $(P<0.01)$ $\mathrm{CO}_{2}$; carbon dioxide, $\mathrm{NH}_{3}$; ammonia, $\mathrm{T}$; temperature, $\mathrm{RH}$; relative humidity, $\mathrm{AF}$; air flow 
Table $\mathbf{3 b}$ The hourly variation in the mean values of $\mathrm{CO}_{2}, \mathrm{NH}_{3}$, temperature, relative humidity and air flow in the solid-floor confinement barn during spring season (MEAN \pm SEM)

\begin{tabular}{|c|c|c|c|c|c|c|}
\hline & \multirow{2}{*}{ Time } & \multicolumn{5}{|c|}{ Spring } \\
\hline & & $\mathrm{CO}_{2}(\mathrm{ppm})$ & $\mathrm{NH}_{3}(p p m)$ & $\mathrm{T}\left({ }^{\circ} \mathrm{C}\right)$ & RH (\%) & $A F(m / s)$ \\
\hline \multirow{24}{*}{ 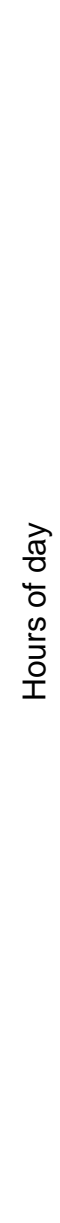 } & 01:00 & $1324.2^{\mathrm{a}} \pm 232.74$ & $17.82 \pm 5.64$ & $18.115^{\mathrm{abc}} \pm 1.654$ & $99.89^{a} \pm 0.11$ & $0.22^{b} \pm 0.013$ \\
\hline & 02:00 & $1313.3^{a} \pm 227.34$ & $15.58 \pm 4.93$ & $17.616^{\mathrm{abc}} \pm 1.662$ & $100.00^{a} \pm 0.00$ & $0.29^{a} \pm 0.010$ \\
\hline & 03:00 & $1232.5^{\mathrm{ab}} \pm 228.06$ & $13.66 \pm 4.32$ & $17.195^{\mathrm{abc}} \pm 1.633$ & $100.00^{a} \pm 0.00$ & $0.01^{c} \pm 0.000$ \\
\hline & 04:00 & $1171.7^{\mathrm{ab}} \pm 213.77$ & $8.43 \pm 2.67$ & $16.774^{\mathrm{abc}} \pm 1.605$ & $100.00^{a} \pm 0.00$ & $0.01^{c} \pm 0.000$ \\
\hline & 05:00 & $1092.5^{\mathrm{abcd}} \pm 204.47$ & $11.05 \pm 3.49$ & $16.196^{\mathrm{abc}} \pm 1.553$ & $99.92^{\mathrm{a}} \pm 0.08$ & $0.01^{c} \pm 0.000$ \\
\hline & 06:00 & $1162.5^{\mathrm{abc}} \pm 211.40$ & $10.41 \pm 3.29$ & $15.925^{\mathrm{abc}} \pm 1.623$ & $100.00^{a} \pm 0.00$ & $0.01^{c} \pm 0.000$ \\
\hline & 07:00 & $890.0^{\text {abcde }} \pm 186.95$ & $7.70 \pm 2.43$ & $14.819^{b c} \pm 1.329$ & $92.46^{\mathrm{ab}} \pm 4.62$ & $0.01^{c} \pm 0.000$ \\
\hline & 08:00 & $296.7^{\mathrm{de}} \pm 43.26$ & $6.60 \pm 2.09$ & $13.942^{\mathrm{C}} \pm 1.172$ & $85.57^{\mathrm{ab}} \pm 5.05$ & $0.01^{c} \pm 0.000$ \\
\hline & 09:00 & $230.8^{\mathrm{e}} \pm 30.83$ & $5.84 \pm 1.85$ & $14.52^{\mathrm{bc}} \pm 1.218$ & $80.86^{\mathrm{abc}} \pm 5.98$ & $0.01^{c} \pm 0.000$ \\
\hline & $10: 00$ & $225.8^{\mathrm{e}} \pm 25.84$ & $5.67 \pm 1.79$ & $15.479^{\mathrm{abc}} \pm 1.303$ & $79.64^{\mathrm{abc}} \pm 5.88$ & $0.01^{c} \pm 0.000$ \\
\hline & $11: 00$ & $427.5^{\text {bcde }} \pm 63.25$ & $6.85 \pm 2.17$ & $17.889^{\mathrm{abc}} \pm 1.640$ & $89.09^{\mathrm{ab}} \pm 5.08$ & $0.01^{c} \pm 0.000$ \\
\hline & $12: 00$ & $768.3^{\text {abcde }} \pm 125.32$ & $7.40 \pm 2.34$ & $19.578^{\mathrm{abc}} \pm 1.657$ & $95.84^{\mathrm{a}} \pm 2.80$ & $0.01^{c} \pm 0.000$ \\
\hline & $13: 00$ & $883.3^{\text {abcde }} \pm 159.19$ & $16.24 \pm 5.14$ & $20.693^{\mathrm{abc}} \pm 1.717$ & $95.22^{a} \pm 3.19$ & $0.01^{\mathrm{c}} \pm 0.000$ \\
\hline & $14: 00$ & $955.0^{\text {abcde }} \pm 173.07$ & $16.56 \pm 5.24$ & $21.736^{\mathrm{abc}} \pm 1.719$ & $94.27^{\mathrm{a}} \pm 3.55$ & $0.01^{\mathrm{c}} \pm 0.000$ \\
\hline & $15: 00$ & $950.8^{\text {abcde }} \pm 175.76$ & $16.83 \pm 5.32$ & $23.439^{\mathrm{a}} \pm 1.696$ & $87.69^{\mathrm{ab}} \pm 4.79$ & $0.01^{c} \pm 0.000$ \\
\hline & $16: 00$ & $837.5^{\text {abcde }} \pm 164.50$ & $17.80 \pm 5.63$ & $22.157^{\mathrm{ab}} \pm 1.521$ & $76.67^{\mathrm{abcd}} \pm 7.45$ & $0.23^{b} \pm 0.021$ \\
\hline & $17: 00$ & $315.0^{\text {cde }} \pm 48.86$ & $15.86 \pm 5.02$ & $21.307^{\mathrm{abc}} \pm 1.416$ & $52.83^{\mathrm{e}} \pm 7.79$ & $0.29^{a} \pm 0.010$ \\
\hline & 18:00 & $207.9^{\mathrm{e}} \pm 3.86$ & $20.55 \pm 6.50$ & $19.736^{\mathrm{abc}} \pm 1.445$ & $57.57^{\text {cde }} \pm 7.05$ & $0.01^{c} \pm 0.000$ \\
\hline & 19:00 & $220.0^{e} \pm 13.38$ & $17.10 \pm 5.41$ & $19.121^{\mathrm{abc}} \pm 1.442$ & $55.29^{\mathrm{de}} \pm 7.50$ & $0.01^{c} \pm 0.000$ \\
\hline & $20: 00$ & $265.8^{\mathrm{de}} \pm 36.18$ & $11.57 \pm 3.66$ & $18.431^{\mathrm{abc}} \pm 1.309$ & $69.90^{\text {cdef }} \pm 6.17$ & $0.01^{c} \pm 0.000$ \\
\hline & $21: 00$ & $750.8^{\mathrm{abcde}} \pm 119.69$ & $10.98 \pm 3.47$ & $19.388^{\mathrm{abc}} \pm 1.550$ & $85.64^{\mathrm{ab}} \pm 3.54$ & $0.01^{c} \pm 0.000$ \\
\hline & $22: 00$ & $1175.0^{\mathrm{ab}} \pm 203.71$ & $10.81 \pm 3.42$ & $19.194^{\mathrm{abc}} \pm 1.597$ & $88.82^{\mathrm{ab}} \pm 3.77$ & $0.01^{c} \pm 0.000$ \\
\hline & 23:00 & $1272.5^{\mathrm{ab}} \pm 237.23$ & $11.04 \pm 3.49$ & $18.924^{\mathrm{abc}} \pm 1.665$ & $96.48^{a} \pm 3.21$ & $0.01^{c} \pm 0.000$ \\
\hline & $24: 00$ & $1377.5^{a} \pm 243.43$ & $14.79 \pm 4.68$ & $18.539^{\mathrm{abc}} \pm 1.679$ & $98.90^{a} \pm 0.98$ & $0.01^{c} \pm 0.000$ \\
\hline
\end{tabular}

a c c d e f:The differences between the means with the different letter in the same column are statistically important. Mean: Average \pm SEM: Standard Error Mean. $(P<0.01)$ $\mathrm{CO}_{2}$; carbon dioxide, $\mathrm{NH}_{3}$; ammonia, $\mathrm{T}$; temperature, $\mathrm{RH}$; relative humidity, $\mathrm{AF}$; air flow 
The highest $\mathrm{CO}_{2}$ value (1553.3 ppm) was detected at 24:00, while the lowest value (794.7 ppm) occurred at 16:00 in the winter. This was followed by values of $815.0 \mathrm{ppm}$ at 17:00 and 913.3 ppm at 12:00. The linear relationship between $\mathrm{CO}_{2}$ and $\mathrm{RH}$ was noteworthy, while there was a non-linear relationship in the day-time (between 10:00 and 17:00). This was caused by opening the doors to allow the animals to move outdoors that resulted in partial ventilation. The highest $\mathrm{CO}_{2}$ value, which was detected at 24:00, was due to closing the doors and increased animal activity. Opening the doors during the night-time resulted in partial ventilation. This situation caused a small decrease in the $\mathrm{CO}_{2}$ value, but the night-time $\mathrm{CO}_{2}$ value was higher than in day-time. The main source of $\mathrm{CO}_{2}$ is respiration of the animals and labourers (Choiniere \& Munroe, 1997). Carbon dioxide is produced under aerobic and anaerobic conditions by microbial fragmentation of organic matter. Water and $\mathrm{CO}_{2}$ are the final products under aerobic conditions and all of the carbon is distributed into the environment as $\mathrm{CO}_{2}$ (Anonymous, 2001). Therefore, $\mathrm{CO}_{2}$ values are higher during times of intensive animal activity. Wathes \& Charles (1994) reported $3000 \mathrm{ppm} \mathrm{CO}_{2}$ as the maximum value. Several researchers have reported the following $\mathrm{CO}_{2}$ concentrations in winter season: $2700 \mathrm{ppm}$ (Kocaman et al., 2006), 4300 ppm (Liang et al., 2005), 1978 ppm (Hörning et al., 2004) and 2100 ppm (Radon et al., 2002). Data collected in the study were below the mentioned limits.

The $\mathrm{NH}_{3}$ values ranged from $4.1 \mathrm{ppm}$ to $18.3 \mathrm{ppm}$ in the winter. These values were below the permitted values reported by Wathes \& Charles (1994). The highest $\mathrm{NH}_{3}$ concentration (18.3 ppm) was detected at 21:00, while the lowest value (4.1 ppm) occurred at 13:00. $\mathrm{NH}_{3}$ values were low in the day-time and high at night-time. Most of the previous studies reported lower $\mathrm{NH}_{3}$ emission values (Baek et al., 2006; Gilliland et al., 2006). Baek et al. (2006) and Flesch et al. (2007) reported that it was measured as lower $\mathrm{NH}_{3}$ concentrations at night-time than that in the day-time. Several researchers revealed the following values for $\mathrm{NH}_{3}$ concentration during the winter season; $28.50 \mathrm{ppm}$ (Redwine et al., 2003), $5.26 \mathrm{ppm}$ (Liang et al., 2003), 48.30 ppm (Wheeler et al., 2003), 20.00 ppm (Guziou \& Beline, 2005), 8.30 ppm (Liang et al., 2005) and $25.06 \mathrm{ppm}$ (Kocaman et al., 2006). Higher $\mathrm{NH}_{3}$ values in the day-time compared to night-time in the present study may be a result of ventilation in the day-time during feeding.

When hourly distribution of inside $\mathrm{T}, \mathrm{CO}_{2}$, and $\mathrm{NH}_{3}$ during winter experimental periods was evaluated, the values of outside $\mathrm{T}$ ranged between $-3.2{ }^{\circ} \mathrm{C}$ and $14.6^{\circ} \mathrm{C}$. Mean values of outside $\mathrm{RH}$ changed from $36 \%$ to $100 \%$. Inside $\mathrm{T}$ values were between $4.9{ }^{\circ} \mathrm{C}$ and $16.8{ }^{\circ} \mathrm{C}$. Although the outside $\mathrm{T}$ reduced to $-3.2^{\circ} \mathrm{C}$, inside $\mathrm{T}$ was $4.9^{\circ} \mathrm{C}$. The inside $\mathrm{RH}$ range was $65 \%-100 \%$. The values were usually more than $90 \%$, while it decreased due to an increase in $\mathrm{T}$. The $\mathrm{CO}_{2}$ values inside the barn were between $200 \mathrm{ppm}$ and $1916.7 \mathrm{ppm}$. The $\mathrm{NH}_{3}$ levels measured inside the barn were $0-91.2 \mathrm{ppm}$. The inside concentration of $\mathrm{CO}_{2}$ was affected by $\mathrm{T}$ and $\mathrm{RH}$. Similarly, inside $\mathrm{NH}_{3}$ was affected by $\mathrm{T}$ and $\mathrm{RH}$ while the measured values were appropriate for dairy cows. This situation once again shows the importance of manure management and ventilation on inside air quality. The harmful gas concentrations in the barn should be kept to a level low enough for the sustainability of animal production and animal welfare.

In the spring season, in terms of the values of $\mathrm{CO}_{2}, \mathrm{NH}_{3}, \mathrm{~T}, \mathrm{RH}$ and $\mathrm{AF}$, the differences in hourly mean values were statistically significant $(P<0.01$; Table 3$)$. In this study, the highest and the lowest $\mathrm{CO}_{2}$ values were measured at 24:00 and 18:00 (1377.5 ppm and $207.9 \mathrm{ppm}$, respectively). The difference between $\mathrm{CO}_{2}$ values was statistically significant $(P<0.01)$. The highest value for $\mathrm{NH}_{3}$ concentrations was measured at 18:00 (20.55 ppm), the lowest value at 10:00 (5.67 ppm). The measured $T$ values in this study ranged between $13.97^{\circ} \mathrm{C}$ and $23.44^{\circ} \mathrm{C}$. T values obtained from the study were within the optimum range for sheep (Ekmekyapar, 2001; Olgun, 2011). In respect of air quality parameters, $\mathrm{NH}_{3}$ and $\mathrm{CO}_{2}$ were at times at a very high level, which could have affected sheep health. T, RH and AF parameters obtained from this study were usually at acceptable levels.

The mean hourly outdoor $\mathrm{T}$ and $\mathrm{RH}$ values varied between $7.7{ }^{\circ} \mathrm{C}$ and $22.1{ }^{\circ} \mathrm{C}$ and $28 \%$ and $75 \%$, respectively, in the spring measurement period (Figure 3). There was an inverse relationship between $\mathrm{T}$ and $\mathrm{RH}$. While there was less than $1{ }^{\circ} \mathrm{C}$ difference between indoor and outdoor $\mathrm{T}$ values during the day-time period (between 9:00 and 18:00), the difference during the night-time period (between 20:00 and 7:00) was up to $10{ }^{\circ} \mathrm{C}$. The indoor $\mathrm{T}$ values were 0.1 to $0.4{ }^{\circ} \mathrm{C}$ lower than the outdoor values at 9:00, 10:00, 11:00, 13:00 and 17:00. This can be explained by the outdoor area being exposed to direct sun radiation and the closed area in the solid-floor confinement barn being in the shade. At the same time, this can be explained by the effect of animals being taken out for feeding during these hours of the day. The lowest indoor T value was $13.4{ }^{\circ} \mathrm{C}$ at 08:00; the second lowest value was $14.5^{\circ} \mathrm{C}$ at 9:00; and the highest $\mathrm{T}$ value $\left(23.4{ }^{\circ} \mathrm{C}\right)$ at 15:00. The indoor $T$ values in the spring measurement period in the experimental barn were appropriate for sheep (Hirning et al., 1994; Olgun, 2011). The lowest indoor RH values during the spring season were 53\% at 17:00 h, with the highest value (100\%) occurring between 24:00 and 6:00 (Figure 3). Indoor RH values were above $80 \%$ during the important part $(80 \%)$ of observation hours. Inadequate ventilation may be the reason for this situation. The indoor $\mathrm{RH}$ values measured were above the recommended limits for ruminants 
during the spring experimental period (Damm, 1997). By changing the ventilation system, the indoor $\mathrm{RH}$ values could be reduced to the desired levels.

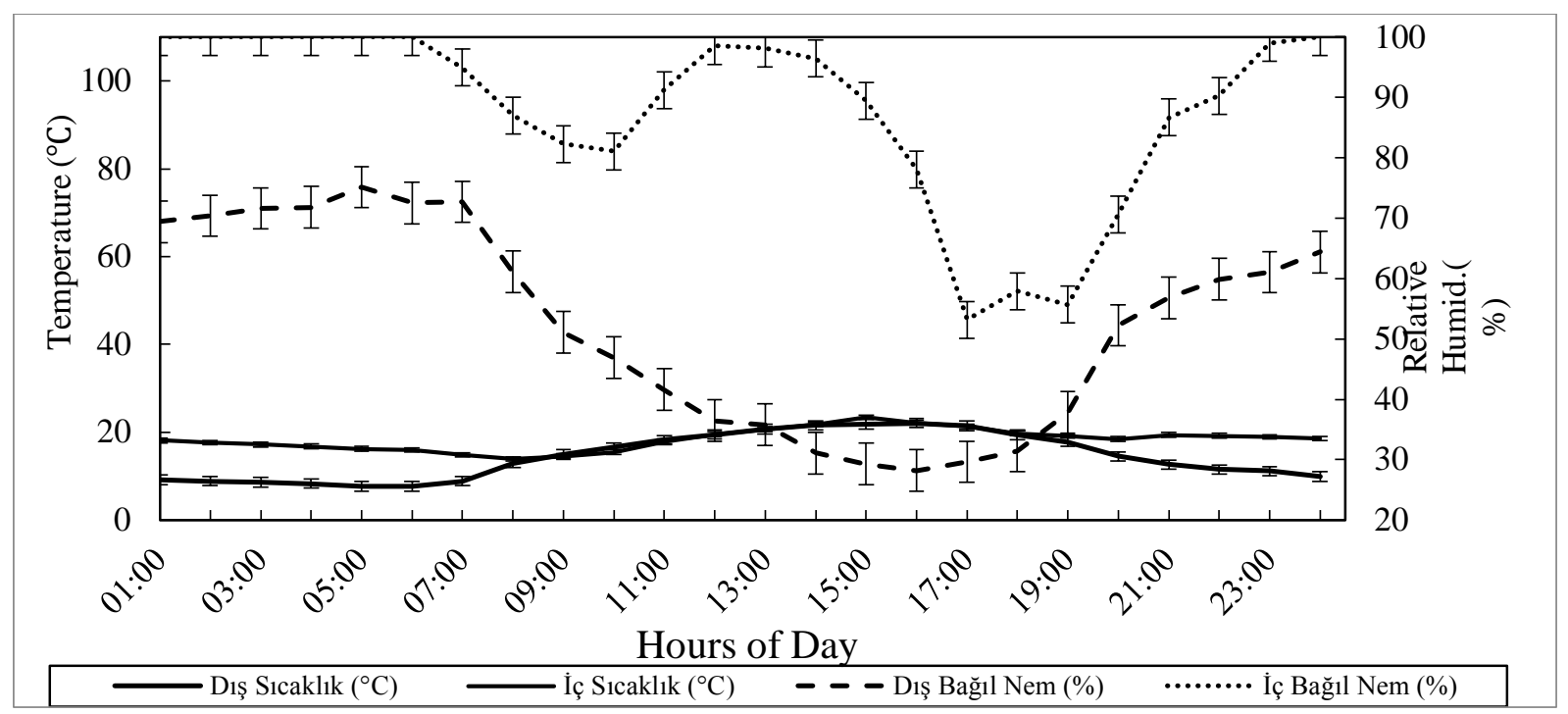

Figure 3 The hourly variation of mean temperature and relative humidity $(\mathrm{RH})$ in solid-floor confinement sheep barn in spring

The highest $\mathrm{CO}_{2}$ value (1377.5 ppm) occurred at 24:00 and the lowest value (207.9 ppm) at 18:00 during the spring measurement period. The second and third lowest $\mathrm{CO}_{2}$ values were measured at 19:00 (220.0 ppm) and 10:00 (225.8 ppm). There was a linear relationship between $\mathrm{CO}_{2}$, and $\mathrm{T}$ and $\mathrm{RH}$ in the spring season in solid-floor confinement barn (Table 3). The highest $\mathrm{CO}_{2}$ values were measured during the hours of 22:00 to 7:00. This was a result of inadequate ventilation in the barn, as well as the barn doors being closed during night hours. $\mathrm{CO}_{2}$ values were very low because animals were taken out for feeding during the periods 8:00 - 10:00 and 17:00 - 19:00.

Average hourly $\mathrm{NH}_{3}$ values in the barn ranged from 5.7 to $20.5 \mathrm{ppm}$. The $\mathrm{NH}_{3}$ values measured during this observation period exceeded the permissible values for animals, reported by Olgun (2011) and Wathes \& Charles (1994). The highest $\mathrm{NH}_{3}$ concentration (20.5 ppm) was measured at 18:00 and the lowest value $(5.7 \mathrm{ppm})$ at 10:00. During the day-time period when the animals were in the experimental barn, the $\mathrm{NH}_{3}$ value was higher than during the night-time period. Mukhtar et al. (2008) reported that $\mathrm{NH}_{3}$ emissions were achieved by $47 \%$ in summer and were lower than in the winter season. Many studies have reported that $\mathrm{NH}_{3}$ emissions are lower in colder periods (Baek et al., 2006; Gilliland et al., 2006). Baek et al. (2006) and Flesch et al. (2007) reported that $\mathrm{NH}_{3}$ emissions were low in the night-time periods. The $\mathrm{NH}_{3}$ values were at or below the permissible level for animals, except for the $20.5 \mathrm{ppm}$ value measured at 18:00 in the spring measurement period. This indicates that if there is inadequate ventilation in the barns, dangerous situations may arise, not only for the animals, but also for humans working in the buildings.

When the variations in hourly averages of $\mathrm{T}, \mathrm{RH}, \mathrm{CO}_{2}$ and $\mathrm{NH}_{3}$ measured during the spring measurement period were evaluated, the indoor $\mathrm{T}$ values ranged from $8.2{ }^{\circ} \mathrm{C}$ to $28.7^{\circ} \mathrm{C}$. The indoor $\mathrm{CO}_{2}$ values were between 200 and $2083.3 \mathrm{ppm}$. The indoor $\mathrm{CO}_{2}$ concentration was affected by $\mathrm{T}$ and $\mathrm{RH}$. Indoor $\mathrm{NH}_{3}$ values were between 0 and $89.8 \mathrm{ppm}$. Similarly, although the level of $\mathrm{NH}_{3}$ was affected by the indoor $\mathrm{T}$ and $\mathrm{RH}$, the measured values were appropriate for animals. This shows the importance of indoor air quality for animal welfare and productivity.

The results of the statistical analysis of the daily mean values of some hazardous gases and climatic parameters in a solid-floor confinement sheep barn obtained during winter and spring seasons are shown in Table 4. In the winter season, in terms of $\mathrm{CO}_{2}, \mathrm{NH}_{3}, \mathrm{~T}$ and $\mathrm{RH}$, the differences in daily mean values were statistically significant $(P<0.01) . \mathrm{CO}_{2}$ values were higher on $\mathrm{d} 1$ and $\mathrm{d} 8$ when the study was conducted, than on the other days. On the other hand, $\mathrm{CO}_{2}$ measurements on $\mathrm{d} 2, \mathrm{~d} 4$ and $\mathrm{d} 6$ were found to be lower than on the other days. The $\mathrm{CO}_{2}$ values measured in the winter season were below the permissible values for animals and people working in a livestock building. Indoor $\mathrm{CO}_{2}$ levels were between 956.2 and 
Table 4 The daily variation in the mean values of $\mathrm{CO}_{2}, \mathrm{NH}_{3}$, temperature, relative humidity and air flow in a solid-floor confinement barn during winter and spring seasons (MEAN \pm SEM)

\begin{tabular}{|c|c|c|c|c|c|c|c|c|c|c|}
\hline \multirow{3}{*}{ Day } & \multicolumn{10}{|c|}{ Seasons } \\
\hline & \multicolumn{5}{|c|}{ Winter } & \multicolumn{5}{|c|}{ Spring } \\
\hline & $\mathrm{CO}_{2}$ & $\mathrm{NH}_{3}$ & $\mathrm{~T}\left({ }^{\circ} \mathrm{C}\right)$ & RH (\%) & $A F(m / s)$ & $\mathrm{CO}_{2}(\mathrm{ppm})$ & $\mathrm{NH}_{3}(\mathrm{ppm})$ & $\mathrm{T}\left({ }^{\circ} \mathrm{C}\right)$ & RH (\%) & $A F(m / s)$ \\
\hline 1 & $1609.7^{\mathrm{a}} \pm 29.7$ & $17.62^{\mathrm{bc}} \pm 5.50$ & $12.82^{\mathrm{abc}} \pm 0.49$ & $95.19^{a} \pm 0.39$ & $0.054 \pm 0.021$ & $201.4^{c} \pm 1.39$ & $0.01^{d} \pm 0.00$ & $10.96^{\dagger} \pm 0.40$ & $100.00^{a} \pm 0.00$ & $0.054 \pm 0.021$ \\
\hline 2 & $1054.9^{c} \pm 67.7$ & $37.34^{\mathrm{a}} \pm 4.89$ & $13.65^{a} \pm 0.27$ & $94.55^{\mathrm{ab}} \pm 0.36$ & $0.050 \pm 0.019$ & $212.5^{c} \pm 10.82$ & $0.01^{d} \pm 0.00$ & $12.26^{\mathrm{ef}} \pm 0.51$ & $97.47^{\mathrm{a}} \pm 1.33$ & $0.050 \pm 0.019$ \\
\hline 3 & $1248.6^{\mathrm{bc}} \pm 103.2$ & $20.22^{b} \pm 5.59$ & $13.30^{\mathrm{ab}} \pm 0.13$ & $94.22^{\mathrm{ab}} \pm 0.25$ & $0.058 \pm 0.023$ & $449.0^{\mathrm{bc}} \pm 75.87$ & $5.82^{c d} \pm 4.09$ & $14.05^{\mathrm{e}} \pm 0.69$ & $90.60^{\mathrm{ab}} \pm 3.75$ & $0.050 \pm 0.019$ \\
\hline 4 & $1041.0^{c} \pm 123.6$ & $18.49^{b c} \pm 4.67$ & $11.99^{\mathrm{bc}} \pm 0.28$ & $90.94^{\mathrm{bcd}} \pm 1.20$ & $0.046 \pm 0.017$ & $955.9^{a} \pm 117.49$ & $8.75^{c d} \pm 4.06$ & $17.98^{d} \pm 0.52$ & $75.23^{\mathrm{bc}} \pm 4.71$ & $0.050 \pm 0.019$ \\
\hline 5 & $1134.7^{\mathrm{bc}} \pm 78.5$ & $11.29^{b c d} \pm 5.42$ & $12.43^{\mathrm{abc}} \pm 0.20$ & $92.12^{\mathrm{abc}} \pm 0.69$ & $0.058 \pm 0.023$ & $1005.9^{a} \pm 118.90$ & $30.30^{a} \pm 6.52$ & $19.43^{\mathrm{cd}} \pm 0.56$ & $83.98^{\mathrm{abc}} \pm 4.08$ & $0.050 \pm 0.019$ \\
\hline 6 & $956.2^{\mathrm{C}} \pm 79.6$ & $2.42^{\mathrm{cd}} \pm 1.58$ & $11.81^{\mathrm{c}} \pm 0.28$ & $87.67^{\text {de }} \pm 1.04$ & $0.067 \pm 0.027$ & $1192.7^{a} \pm 134.80$ & $24.76^{\mathrm{ab}} \pm 2.39$ & $21.01^{\mathrm{abc}} \pm 0.61$ & $90.18^{\mathrm{ab}} \pm 3.30$ & $0.050 \pm 0.019$ \\
\hline 7 & $1236.1^{b c} \pm 50.9$ & $0.01^{d} \pm 0.00$ & $12.04^{\mathrm{bc}} \pm 0.23$ & $92.61^{\mathrm{abc}} \pm 0.80$ & $0.054 \pm 0.021$ & $1150.3^{a} \pm 137.38$ & $16.40^{\mathrm{bc}} \pm 1.90$ & $21.59^{\mathrm{abc}} \pm 0.61$ & $86.12^{\mathrm{abc}} \pm 4.73$ & $0.050 \pm 0.019$ \\
\hline 8 & $1466.0^{\mathrm{ab}} \pm 31.4$ & $0.61^{d} \pm 0.41$ & $12.42^{\mathrm{abc}} \pm 0.28$ & $92.21^{\mathrm{abc}} \pm 0.30$ & $0.050 \pm 0.019$ & $1110.4^{a} \pm 137.29$ & $12.31^{\mathrm{bcd}} \pm 1.33$ & $22.4^{\mathrm{ab}} 8 \pm 0.66$ & $86.40^{\mathrm{abc}} \pm 4.14$ & $0.046 \pm 0.017$ \\
\hline 9 & $1156.1^{\mathrm{bc}} \pm 56.0$ & $0.01^{d} \pm 0.00$ & $10.25^{d} \pm 0.36$ & $87.23^{\mathrm{e}} \pm 0.72$ & $0.050 \pm 0.019$ & $904.9^{\mathrm{ab}} \pm 130.41$ & $15.00^{\mathrm{bc}} \pm 1.16$ & $23.51^{a} \pm 0.48$ & $71.96^{\mathrm{c}} \pm 4.76$ & $0.054 \pm 0.021$ \\
\hline 10 & $1133.3^{\mathrm{bc}} \pm 68.5$ & $0.01^{d} \pm 0.00$ & $8.75^{\mathrm{e}} \pm 0.25$ & $90.39^{\text {cde }} \pm 1.45$ & $0.050 \pm 0.019$ & $878.3 \pm 124.50$ & $10.44^{\mathrm{cd}} \pm 1.29$ & $20.37^{\mathrm{bcd}} \pm 1.14$ & $85.78^{\mathrm{abc}} \pm 3.77$ & $0.058 \pm 0.023$ \\
\hline
\end{tabular}

a $\mathrm{b}$ c d e f. The differences between the means with the different letter in the same column are statistically important. Mean: Average \pm SEM: Standard Error Mean. $(P<0.01)$ $\mathrm{CO}_{2}$; carbon dioxide, $\mathrm{NH}_{3}$; ammonia, $\mathrm{T}$; temperature, $\mathrm{RH}$; relative humidity, $\mathrm{AF}$; air flow 
$1609.7 \mathrm{ppm}$. The lowest average $\mathrm{CO}_{2}$ value was measured on $\mathrm{d} 6$, the highest average $\mathrm{CO}_{2}$ value was measured on $d 1$. Wathes \& Charles (1994) and Olgun (2011) suggested that the maximum limit for $\mathrm{CO}_{2}$ is $3000 \mathrm{ppm}$. The $\mathrm{CO}_{2}$ data from this study were below the limit allowed for animals. In the winter period, the daily mean values of $\mathrm{NH}_{3}$ ranged from 0.01 to $37.3 \mathrm{ppm}$. The same researchers reported a maximum limit of $20 \mathrm{ppm}$ for persistent $\mathrm{NH}_{3}$ in animal shelters. The $\mathrm{NH}_{3}$ were found to be well below the dangerous limit for animals in the winter. The lowest daily average $\mathrm{NH}_{3}$ value was measured on $d 7, d \mathrm{~g}$ and $\mathrm{d} 10$, while the highest average $\mathrm{NH}_{3}$ value was measured on $\mathrm{d} 2$. In the winter period, indoor $\mathrm{T}$ values varied from $8.7^{\circ} \mathrm{C}$ to $13.7^{\circ} \mathrm{C}$, while $\mathrm{RH}$ values ranged from $87 \%$ to $95 \%$. It was determined that $\mathrm{CO}_{2}$ and $\mathrm{NH}_{3}$ emission increased with increasing $\mathrm{T}$. RH values in the winter season were well above the recommended values for sheep, while indoor $T$ values were within the recommended $T$ values for sheep. The same researchers (Wathes \& Charles, 1994; Olgun, 2011) reported that in the cold regions they could allow RH up to $80 \%$ for sheep and goats in the winter. $\mathrm{RH}$ values in winter were well above the permissible limit.

In the spring season, in terms of the values of $\mathrm{CO}_{2}, \mathrm{NH}_{3}, \mathrm{~T}$ and $\mathrm{RH}$, the differences in daily mean values were statistically significant $(P<0.01)$. Results presented in Table 4 show that $\mathrm{CO}_{2}$ and $\mathrm{NH}_{3}$ levels were high on days when both $\mathrm{T}$ and $\mathrm{RH}$ values were equally high (days $5,6,7$ and 8). In particular, $\mathrm{CO}_{2}$ reached its highest value (1192.7 ppm) on d 6 when $\mathrm{T}$ and $\mathrm{RH}$ values were equally high. $\mathrm{CO}_{2}$ values were between $201.4 \mathrm{ppm}$ and $1192.7 \mathrm{ppm}$. Wathes \& Charles (1994) and Olgun (2011) suggested that the maximum limit for $\mathrm{CO}_{2}$ is $3000 \mathrm{ppm}$. The measured values were below the limit allowed for animals. The daily mean values of $\mathrm{NH}_{3}$ ranged from $0-30.3 \mathrm{ppm}$ during the experimental period. The lowest daily average $\mathrm{NH}_{3}$ value was measured on $\mathrm{d} 1$ and $\mathrm{d} 2$, and the highest average $\mathrm{NH}_{3}$ value was measured on $\mathrm{d} 6$. The measured $\mathrm{NH}_{3}$ values during the study were generally below the dangerous limits for animals (Wathes \& Charles, 1994; Olgun, 2011). Indoor $\mathrm{RH}$ values ranged from $73 \%$ to $100 \%$ in the spring season. While the highest $\mathrm{RH}$ values werer measured on $\mathrm{d} 1$ and $d 2$, the lowest $\mathrm{RH}$ value was measured on $\mathrm{d} 9$. Indoor $\mathrm{T}$ values were within the optimum range for sheep during the first three days of the study, and within suitable $T$ values for sheep on other days. Indoor RH values in the same measurement period were well above the optimum range for sheep.

To obtain an overview of correlations between parameters, Principal Component Analysis (PCA) was performed in this study and the results are presented in Table 5 . In the winter season, the first four PCs accounted for $88 \%$ of total variance. $\mathrm{RH}$ and $\mathrm{CO}_{2}$ exhibited high positive values for $\mathrm{PC} 1$ in all data. The other parameters are in different PCs. In the summer season, the first three PCs accounted for $93 \%$ of total variance. $\mathrm{T}$ and $\mathrm{NH}_{3}$ exhibited high positive values for $\mathrm{PC} 1$ in all data. $\mathrm{AF}$ was positive for $\mathrm{PC} 2, \mathrm{RH}$; and $\mathrm{CO}_{2}$ was positive for PC3.

Table 5 Principal Component $(\mathrm{PC})$ loadings of parameters according to seasons

\begin{tabular}{|c|c|c|c|c|c|c|c|}
\hline \multirow{3}{*}{$\begin{array}{l}\text { Season } \\
\text { variable }\end{array}$} & \multicolumn{7}{|c|}{ Season } \\
\hline & \multicolumn{4}{|c|}{ Winter } & \multicolumn{3}{|c|}{ Spring } \\
\hline & PC1 & PC2 & PC3 & PC4 & PC1 & PC2 & PC3 \\
\hline $\mathrm{T}$ & 0.538 & 0.135 & 0.318 & 0.593 & 0.520 & -0.212 & -0.280 \\
\hline $\mathrm{RH}$ & 0.577 & 0.100 & -0.242 & 0.200 & -0.468 & -0.157 & 0.535 \\
\hline $\mathrm{CO}_{2}$ & 0.501 & -0.014 & -0.554 & -0.508 & 0.409 & -0.302 & 0.745 \\
\hline $\mathrm{NH}_{3}$ & 0.351 & -0.498 & 0.643 & -0.446 & 0.532 & -0.122 & 0.041 \\
\hline $\mathrm{AF}$ & 0.060 & 0.850 & 0.346 & -0.388 & 0.248 & 0.908 & 0.280 \\
\hline
\end{tabular}

T; temperature, $\mathrm{RH}$; relative humidity, $\mathrm{CO}_{2}$; carbon dioxide, $\mathrm{NH}_{3}$; ammonia, $\mathrm{AF}$; air flow

\section{Conclusion}

Based on the results of this study, it was determined that indoor climatic parameters have a significant effect on the formation of harmful gases. In addition, the levels of harmful gases in sheep housing at times reached levels that would adversely affect animal health and welfare. However, it is possible to have animal housing that increases the quantity and quality of production and also enables good standards of animal welfare. For this purpose, animal shelters should be planned in accordance with animal health and welfare standards, as well as ambient air quality suitable for animal health. Adequate and regular ventilation should be provided in the shelters. Manure should be collected at regular intervals and stored in suitable areas. In a 
newly developed sheep housing system, it is important to focus on providing adequate air quality and welldesigned manure management in order to increase animal production and welfare. Reduction in harmful gases which have negative effects on animal production, and cause environmental pollution, is a critical factor which should be noted with new sheep barn designs that should also take into account the ambient air quality appropriate for animal welfare.

\section{Acknowledgements}

This paper was produced from the project results (Project number 11401007) supported by the Scientific Research Projects Coordination Unit of Selçuk University. Data from this study (the daily variation of winter data in this study) were presented at the Balnimalcon 2017 8th Balkan Animal Science Conference and only the abstract was published in the abstract book of symposium.

\section{Authors' Contributions}

Conception, design, data collection, drafting of paper - SU; Stastical analysis - Fi.

\section{Conflict of Interest Declaration}

There are no conflicts of interest.

\section{References}

Anonymous., 2001. Emissions from animal feeding operations, U.S. Environmental Protection Agency, Triangle Park NC 27711.

Anonymous., 2006. UN Food and Agriculture Organization. Livestock's long shadow: environmental issues and options. UN Food and Agriculture Organization, Rome.

Asman, W.A.H., 1992. Ammonia emission in Europe: Updated emission and emission variations, Report no. 228471008 RIVM Bilthoven, The Netherlands. p. 88.

Baek, B.H., Todd, R., Cole, A. \& Koziel, J.A., 2006. Ammonia and hydrogen sulphide flux and dry deposition velocity estimates using vertical gradient method at a commercial beef cattle feedlot. Int. J. Global Environ. Issues 6 (2-3), 189-203.

Berge, E., 1997. Housing of sheep in cold climate. Livest. Prod. Sci. 49, 139-149.

Blunden, J. \& Aneja, V.P., 2008. Characterizing ammonia and hydrogen sulfide emissions from a swine waste treatment lagoon in North Carolina. Atmos. Environ. 42 (14), 3277-3290.

Brosh, A., Aharoni, Y., Degen, A.A., Wright, D. \& Young, B.A., 1998. Estimation of energy expenditure from heart rate measurements in cattle maintained under different conditions. J. Anim. Sci. 76, 3054-3064.

Budisatria, I.G.S., Udo, H.M.J., Van der Zijpp, A.J., Murti, T.W. \& Baliarti, E., 2007. Air and water qualities around small ruminant houses in Central Java, Indonesia. Small Rumin. Res. 67, 55-63.

Caroprese, M., 2008. Sheep housing and welfare. Small Rumin. Res. 76, 21-25.

Choiniere, Y. \& Munroe, A.J., 1997. Air quality inside livestock barns. Ministry of Agriculture and Food, AGDEX 400/717, Factsheet, Ontorio, USA.

Clark, J.A. \& McArthur, A.J., 1994. Thermal Exchanges. In: Wathes, C.M. \& Charles, D.R. (Eds). Livestock Housing. CAB International, Wallingford. pp. 97-122.

Curtis, S.E., 1983. Environmental Management in Animal Agriculture. Iowa State University Press, USA.

Damm, T., 1997. Stallbau, Landwirtscahftsverlag GmbH, Münster-Hiltrup, 139-141.

Ekmekyapar, T., 2001. Tarımsal Yapılar, Atatürk Üniversitesi Ziraat Fakültesi Ders Yayınları No 204.

Fangmeier, A., Hadwiger-Fangmeier, A., Van der Eerden, L.J. \& Jäger, H.J., 1994. Effects of atmospheric ammonia on vegetation. A review. Environ. Pollut. 86, 43-82.

Flesch, T.K., Wilson, J.D., Harper, L.A., Todd, R.W. \& Cole, N.A., 2007. Determining ammonia emissions from a cattle feedlot with an inverse dispersion technique. Agric. For. Meteorol. 144, 139-155.

Geigenmüller, M.R., 1992. Brauchen Schafe einen Stall? Landtechnik 9, 424-426.

Gilliland, A.B., Appel, K.W., Pinder, R.W. \& Dennis, R.L., 2006. Seasonal NH 3 emissions for the continental United States: Inverse model estimation and evaluation. Atmos. Environ. 40, 4986-4998.

Guiziou, F. \& Beline, F., 2005. In situ measurement of ammonia and greenhouse gas emissions from broiler houses in France. Biores. Technol. 96, 203-207.

Hartung, J., 1994. Environment and Animal Health. In: Livestock Housing. Eds: Wathes, C.M. \& Charles, D.R., Cambridge University Press, Cambridge. pp. 25-48.

Hirning, H.J., Faller, T.C., Hoppe, K.J., Nudell, D.J. \& Ricketts, G.E., 1994. Sheep Housing and Equipment Handbook. Midwest Plan Service, lowa State University, Ames lowa, USA.

Hörnig, G., Brunsch, R., Stollberg, U., Jelinek, A., Pliva, P. \& Ėespiva, M., 2004. Ammonia, methane and carbon dioxide emissions from laying hens kept in battery cages and aviary systems, 2nd Agricultural Engineering Conference of Central and East European Countries, Prauge, Czech Republic, 19-23 April 2004.

Kılıç, İ. \& Şimşek, E., 2009. Hayvan barınaklarından kaynaklanan gaz emisyonları ve çevresel etkileri, Uludağ Üniversitesi Mühendislik-Mimarlık Fakültesi Dergisi, Cilt 14, Sayı 2, 151-160.

Kocaman, B., Esenbuga, N., Yıldız, A., Laçin, E. \& Macit, M., 2006. Effect of environmental conditions in poultry houses on the performance of laying hens. Int. J. Poult. Sci. 5, 26-30 
Liang, Y., Xin, H.,Tanaka, A., Lee, S.H., Li, H., Wheeler, E.F., Gates, R.S., Zajaczkowski, J.S., Topper, P.A. \& Casey, K.D., 2003. Ammonia emissions from layer houses in Iowa. International Symposium on Gaseous and Odour Emissions from Animal Production Facilities, 1-4 June 2003, Horsens, Denmark.

Liang, Y., Xin, H., Wheeler, E.F., Gates, R.S., Li, H., Zajaczkowski, J.S., Topper, P.A., Casey, K.D., Behrends, B.R., Burnham, D.J. \& Zajaczkowski, F.J., 2005. Ammonia emissions from US. laying hen houses in lowa and Pennsylvanıa. Transactions of the ASAE, Vol 48 (5), 1927-1941.

Metz, B., Davidson, O.R., Bosch, P.R., Dave, R. \& Meyer, L.A., 2007. Climate Change 2007: mitigation. Contribution of Working Group III to the Fourth Assessment Report of the Intergovernmental Panel on Climate Change. Cambridge University Press, New York, NY, USA.

Minitab, 2013. Minitab for Windows. Release 16., Minitab Inc., New-York, ABD.

Mukhtar, S., Mutlu, A., Capareda, S. \& Parnell, C.B., 2008. Seasonal and spatial variations of ammonia emissions from an open-lot dairy operation. J. Air Waste Manag. Assoc. 58, 369-376.

Olgun M., 2011. Tarımsal Yapılar, Agricultural Faculty Lecturer Publication No 1577. Ankara University, Ankara, Türkiye.

Phillips, S.B., Arya, S.P. \& Aneja, V.P., 2004. Ammonia flux and dry deposition velocity from near-surface concentration gradient measurements over a grass surface in North Carolina. Atmos. Environ. 38, 3469-3480.

Radon, K., Danuser, B., Iversen, M., Monso, E., Weber, C., Hartung, J., Donham, K.J., Palmgren, U. \& Nowak, D., 2002. Air contaminants in different European farming environments. Ann. Agric. Environ.Med. 9, 41-48.

Redwine, J.S., Lacey, R.E., Mukhtar, S. \& Carey, J.B., 2003. Concentration and emissions of ammonia and particulate matter in tunnel ventilated broiler houses under summer conditions in Texas. Transactions of the ASAE, 45 (4), 1101-1109.

Schnoor, J.L., Thorne, P.S. \& Powers, W., 2002. Fate and transport of air pollutants from cafos, pp. 86100. Iowa concentrated animal feeding operation air quality study. Environmental Health Sciences Research Center, University of lowa, http:// www.publichealth.uiowa.edu/ehsrc/ CAFOstudy

Sevi, A., Annicchiarico, G., Albenzio, M., Taibi, L., Muscio, A. \& Dell'Aquila, S., 2001. Effects of solar radiation and feeding time on behaviour, immune response and production of lactating ewes under high ambient temperature. J. Dairy Sci. 84, 629-640.

Uğurlu, N. \& Uzal Seyfi, S., 2010. Çiftlik Yapıları ve Hayvan Barınakları. Kültürteknik. Eds: Kara, M ve Çiftçi, M. ISBN: 978-605-61635-0-0), 269-298.

Uzal Seyfi, S. \& Dursun, Ş., 2011. Indoor air quality in loose dairy housing in spring and the effects of gas emission on environmental pollution. Int. J. Sust. Water Environ. Systems Volume 3, No. 2, 59-64. http://www.iasks.org/sites/default/files/swes20110302059064.pdf

Uzal Seyfi, S., 2013. Hourly and seasonal variations in the area preferences of dairy cows in freestall housing, J. Dairy Sci. 96, 906-917.

Walker, J.T., Robarge, W.P., Shendrikar, A. \& Kimball, H., 2006. Inorganic PM2.5 at a U.S. Agricultural site. Environ. Pollut. 139, 258-271.

Wathes, C.M. \& Charles, D.R., 1994. Livestock Housing. Wallingford (UK), CAB International.

Wheeler, E.F., Zajaczkowski, J.S., Topper, P.A., Gates, R.S., Xin, H., Casey, K.D. \& Liang, Y., 2003. Ammonia emissions from broiler houses in Pennsylvania during cold weather. International Symposium on Gaseous and Odour Emissions from Animal Production Facilities. 1-4 June 2003, Horsens, Denmark. 